sources, which is a useful thing to do. I did that with a lot of criticism, and it just falls apart in your hands if you do that. Anyway, I had that experience behind me, and then I was living in France, and France is one of those places that we have an enormously elaborate set of assumptions about. I knew that I was not living in a country anyone had ever described to me. It was that same feeling that I had been told wrong. So I started reading about French law and French sociology, and all kinds of things, and again sort of making another model of reality so that I could get rid of the one I had been given that was wrong. Even Housekeeping is written, I think, from the point of view of very great agnosticism as far as accepting the importance or the reality of all kinds of things that people take to be important and real.

\title{
Portrait of Marilynne Robinson
}

\author{
Anne E. Voss
}

Marilynne Robinson, author of Housekeeping and Mother Country, is one of the finest writers now living and also one of my favorites. I'm not alone, though, in my certain appraisal. Housekeeping, published in 1982 when she was thirty-eight, was nominated for a Pulitzer and won the Hemingway Foundation Award for Best First Novel. Mother Country, published in 1988, was nominated for the National Book Award in nonfiction. Still more important is the way I've heard readers talk about these books, particularly Housekeeping. Often they remember it as fondly as they remember a first love, their recollection expressed in wistful present tense superlatives and memorized quotations. "It's a book," one told me, "that I not only read but felt."

As soon as I heard that Marilynne had been invited to join Writers' Workshop faculty at the University of Iowa, I knew I wanted to interview her. I first saw her, though, at not one but two screenings of the recent Hamlet. Both times, just as the lights dimmed, she rushed down the aisle alone with her hands thrust deeply into the patch pockets of a dark woolen coat. Both times, by coincidence, she assumed the seat directly in front of me, slouching deeply into it, never shrugging off her coat, hardly moving 
through the entire film, staying until its bitter end. Then quietly she slipped out again.

When I met her a few weeks later, I asked her how many times she'd seen it. "Four," she replied. In her office, Marilynne was wrapped in an oversized lambswool sweater and swirling silk skirt, her straight brown hair side-parted and loose. Its ends grazed her coat, long and black, unbuttoned but still protecting her, like Zeus's aegis. "I'm in my Hamlet phase right now," she confided. "You know, I've been thinking recently that Hamlet has been misinterpreted. Don't you think that Claudius actually gives Hamlet exactly what he wants? I don't think that Hamlet really wants to be King of Denmark. He just wants to read his books."

Marilynne wasn't at home when I arrived for our appointment, but her eldest son, James, heir to his mother's wide eyes and rounded face, told me she was expected back soon as he pushed back a lock of his own straight hair. He then offered me a chair and amused me while we waited, along with their loopy black pug dog, Chester. Marilynne never showed, but she did call me later, apologizing and offering to meet me at my apartment the next weekend. "My son Joseph usually has his high school friends over on Friday night. Could you pick me up and we can talk at your house?"

As we drove across town, through the remnants of the latest snowstorm, I told her that I'd thought James resembled her. "I do, too," she said eagerly, pushing back her hair. "Although most people don't think so," she added. Greeted at the door by my skittery cat, Audrey, Marilynne shed her coat and accepted a glass of red wine and a seat on my battered sofa. She was dressed simply in jeans, a cowlneck sweater and low black lace-up boots, her hair slightly wild from heat and static, her cheeks wide, and red from the bitter cold.

Excited and not sure where to begin, I told Marilynne that I thought people would like to know more about her childhood. Having sprung into literature fully grown like Athena, she was still a mystery, and commentary on her background was limited mostly to her two book jackets. "Then if you don't know about it, I can just make it up," she smiled, sipping the wine, shy before the story.

"I don't talk to people a great deal," she admitted. "I've found that if a person has any sort of privacy at all, people are instantly terrified of intruding, at least the people who read me. I have a special readership of gentle 
spirits. . . I I don't know. I was born in Sandpoint, which is where Housekeeping is set. I grew up in towns in Idaho. My family had always lived there and still lives there. My great-grandparents settled there.

"I spent my early, early formative period in a little non-town called Coulin, which I guess is named after those cliffs in Scotland, which was, I swear, just three houses and a store when I was a child, and this wonderful lake. And my father was always in the lumber industry and when I was very young he was actually sometimes a lumberjack. He was still very much in the woods then and he always came home smelling of sawdust and pitch. It was very lovely."

Marilynne leaned back and smiled, raking her hair with her fingers before she continued. "My mother was interesting. She's very verbal and witty. Good company. I liked having her around. She used to do things like she read us Edward Lear endlessly. She had these strange poems that she liked and Gulliver's Travels and things like The Yearling and Heidi and, oh, I don't know, books of that kind. She read to us a lot and she had good taste in what she read. I mean, she still is somebody with a very good sense of language, too, and a nice reading voice. I think that probably the voice in my writing, if it has an origin, it's probably my mother's voice."

She paused. My cat had decided it was safe now to scout the intruder. She came up and sniffed cautiously. "She must smell Chester," Marilynne told me as she stroked the back of Audrey's head with her finger. I smiled, relaxing into my chair. Did you always want to be a writer? I continued.

“" 'From childhood's hour' as Edgar Allen Poe would say, and then when I didn't write for years, that did not disturb the idea that I was a writer. I felt pretty secure with my vocation of choice. I wrote my dissertation, but that never has made a writer of anybody, so I still was a writer who had not written. And then when I wrote Housekeeping, in a way it was done to demonstrate to me that I could write, but then it wasn't such a big deal. I didn't feel any more like a writer after I'd written the book than before. It was really very strange. It was a very private sort of thing. I was very serious about it and at the same time, it didn't imply printed pages or readers. It was really something else.

"My brother thought I was going to be a poet, then I think it became pretty clear to us after a while that I was not going to be a poet. When I was young, my poetry was so precocious that it covered many sins, but when I got to be sixteen and seventeen and I was still precocious ... You 
know, I could have been twenty-eight and still been precocious. After a while I realized that there was nothing going on, so I started writing prose just as a way of getting around the problems of that." Marilynne's voice stopped briefly. Were you and your brother close, I asked.

"I really admired David. He's very smart and he's very funny and he's a wonderful ... . well, from an early age he could draw beautifully and make these amazing pictures, and so on. He was also, you know, very teasing and badgering, that sort of thing. He was always my biggest admirer, in a way. Everything he did or knew or read I had to also know and have read. I read most of Plato's dialogues and The Republic and a lot of Aristotle and all kinds of things like that because my brother was always saying to me:"

She shook her finger down at an imaginary younger Marilynne, "“What?! You haven't read Aristotle?!'”

“"No!"” Marilynne clutched her hands to her breast and shifted her voice into falsetto, letting it trip down the scale to its last note, in imitation of the imperiled heroine of nineteenth century melodramas. Startled, my cat scrambled toward the kitchen.

Marilynne dropped her hands and laughed, "My brother's a very smart man, and he was a very funny kid, and he had a sort of wizard quality about him, always knowing more about things than I could quite believe he could know. He was a very demanding brother and he talked to me all the time about everything. He had his ambitions for both of us, you know, and there was something very generous and reassuring about that. David saw me as another self in a lot of ways, I think, and he liked that I wrote, and I would write for him and he would draw for me, and he never condescended to me in terms of what my aspirations should be. I just felt safer with him than with anyone else. I felt as if he knew me better than anyone else in ways that really mattered."

Her family moved around a lot when Marilynne was younger, the lumber company sending her father "from one quaint little town to another. Really, I moved around quite a lot in a very small space. I have travelled widely in Idaho!" By the time she was in high school, the family had settled in Coeur d'Alene, which is high in northern Idaho, near Spokane, Washington. The Idaho school systems taught a traditional curriculum that included a great deal of Latin, and Marilynne excelled in school. She was never very social, having become "one of those bookish girls" who would hang out with other bookish girls, reading every library book they could carry, the older the better. 
"I don't remember there being very much junk around to read. There was a big old stodgy library that I used to go to and it was very serious. It was serious to the point of being grim! It had books in it that were the important books of ages gone by, things that had gone out of style but had never lost their sense of incredible significance. I read lots. I read old books. You know, I thought the older the book was somehow the more authority it had, sort of Chinese. There was a time when I'd read anything about Oliver Cromwell, and that's the truth."

One day soon after, when I visited her class, Marilynne ran into the room several minutes past the hour, her coat unbuttoned, books falling through the folds of her arms, a satchel style shoulder bag dragging at her elbow, almost spilling its contents. "Sorry, I'm late," she sputtered breathlessly. "I was reading material speculating on the authors of the Old Testament. Did everyone finish reading Genesis for today?"

In 1962, after high school in Coeur d'Alene, she followed her brother to Rhode Island, where he was studying art and art history at Brown. Indeed, Marilynne's fondest memories of Brown were from her freshman year, spent with David who was then a senior. "He always went around with some 'Hmmm,' some big black thought bubble in his head, you know, and he would take me on these kind of trudges around Providence, in the rain, by preference I think, and talk to me about whatever it was that he was ruminating on at the time and it was always something very, very abstract. And we would walk miles and miles and destroy our clothes, and then we'd go have some dreadful Chinese food somewhere and talk and talk. It was the most intellectually serious period of my life and it was mainly because of him, with Brown just sitting there as a backdrop."

At Pembroke, Brown's sister college, Robinson indulged her intellectual bent. Afraid that she might be underprepared because of her background, Robinson discovered that Idaho's traditional curriculum had actually given her an advantage. She majored in American literature and took a smattering of courses in related areas-Victorian literature, French, Latin, philosophy and, also, theology.

"It went very nicely with American literature. So many of the early writers were either theologians or people who were writing criticism of theology. The attractions to me are aesthetic, but I think that any attraction that merits the name 'attraction' is. I think that one of the things that is a sad loss is the intellectual history of Christianity. It is a profound intel- 
lectual tradition and has stimulated an enormously important - what is the word I want? - so many other energies spinning off it, and we have just decapitated the whole tradition."

Marilynne said she was often shuttled to church as a child, wearing white gloves into which she stuffed her collection box money so that the coins splayed the tips like alien fingers. One memorable Easter Sunday, she listened intently as the minister wondered about the being Mary met at the empty tomb, who appears in all of the Gospels but in a different guise in each one. "Was the man an angel?" the lace-frocked minister asked his congregation. "Or is this even a meaningful question?"

"It was the first time I'd ever heard someone work through a text and talk about metaphor," she reflected.

She also studied poetry at Brown. "I'd memorized a lot of poetry in high school. I used to do it all the time. I don't know why. I memorized all kinds of things, like Edna St. Vincent Millay." Marilynne sat up suddenly on the sofa and began to recite:

"All I could see from where I stood / Were three long mountains and a wood ..."

With each stanza her voice grew stronger and more certain of her memory, as she relaxed into her role. I'd noticed before that Marilynne could be quite shy in public. In readings she'd given, I'd listened as her voice travelled fast and determined at the beginning, slowing to its own assured tone as she neared the end.

She remembered the whole poem, quite lengthy, and at its end, I applauded her. "Don't get me started," she warned me, laughing. "I wish I'd done more. I wish I'd memorized more. It's music and rhythm. When I talk about writing, I always say that written language is sheet music. It should have exactly the same pleasures as music."

Marilynne also took her first creative writing course at Brown, with John Hawkes. She said he was a noted tyrant on the campus, and Marilynne's freshman roommate dared her to prove that she was a writer by taking a class with him. During the height of "Hemingway Minimalism," her prose style, with its extended metaphors, was sharply criticized by the other students in the class. Hawkes defended her, though. "She's doing exactly what she ought to do. This is her voice," he told the class.

"There is a way in which you have to create a syntax that's amenable to your style of thinking," Marilynne continued. "If your style of thinking 
tends toward irony or reflection or ambivalence or whatever, then inevitably you push for syntaces that accommodate it. Simple sentences aren't adequate for weighing one thing against another, attenuating or amending. You can't translate the same kind of thinking from one kind of language to another."

She owed much to Hawkes's support. "He was perfect," she added, then said dryly, "In many ways, my life is a tedious chronicle of good luck." She was right. Even the story of Housekeeping sounded charmed. She began it after her children had entered school, while writing her doctoral thesis on "The Second Part of Henry the Sixth." She'd been told that it was impossible to write both academic prose and fiction, so to prove to herself that she hadn't lost her childhood talents she began writing scenes as she worked on her dissertation, stuffing these scraps into the drawer of an old 1930s sideboard in their house.

Soon after she'd completed her doctorate, she was talking to a family friend and he mentioned that he'd received some fiction from a student. " 'I used to write,' I said to him. And he said he'd be interested in seeing something I'd written. I was too embarrassed to show him anything that was old and the new stuff was all on scrap paper, so I went to the library. And fell asleep! And when I woke up, I wrote for hours and what I wrote was the whole scene of the train wreck (the opening scene of Housekeeping). And he liked it!"

She found that many of those sideboard scraps fit into an apparent order, so she continued from there. "I didn't think it was publishable and I wrote it taking great pleasure in the fact that it was a completely unpublishable book. I just wrote it for myself. In fact, when Bill Forsythe (the director of the movie Housekeeping) read it he said his first reaction was that you could never make a film out of that book. All the major scenes occur in darkness! It sounded like there was an affinity of mind."

Rugged individualists both, I noted. "Either you're a rugged individualist or you're a fool!" Marilynne nodded her head emphatically, then remarked, "I sounded like a western writer just at that moment, didn't I? I like being called a western writer. I even think I deserve to be called a western writer. It may be a distinction that is fading but I do. I even think that Housekeeping is a western book. And I think Westerners know whą I mean.

"One of the things actually that I wanted to do with Housekeeping was 
to create, to objectify a point of view that I came from. When I was at school at Brown, people knew on a map where I was from but they wondered, 'Why is someone from Idaho interested in metaphysics?' The idea that there was any deep content in the West. . . People thought that if you were from the West you were supposed to write about stirrups. A lot of things that are in Housekeeping are strange odds and ends from my family history. There are little private bits and allusions. It was sort of like making a quilt. You take scraps of all the little things in your past and put them in the right configurations. So I had that. I did it so that my children would know what was inside my head, and my brother, and to please my mother and my father and to remember my grandparents. And really that was what I was writing."

Did she have any regrets in not starting to write earlier? "I feel as though if I wrote a lot, I would write many lesser books. Every once in a while, I take myself to the library and make myself aware that the world really does not need one more book unless it's ..." She lingered here, rubbing her hands along the wine glass. I felt, suddenly, strongly, that I was intruding. "No point in doing it unless you're going to put a serious effort into it," she continued finally. There was a pause, then a softer voice.

"When I think of myself as a writer, I mean, basically my development was arrested when I was very young. The curiosities I had at that time are still with me. It's myself being faithful to my earliest ideas." She laughed. "It's sort of like I'm saying, 'I haven't forgotten you, you strange child. You and I know what this conversation is about." She laughed again, more deeply, out loud but to herself. 